\title{
Interview with Jo Berry, 6 May 2014
}

\begin{abstract}
In the following interview, Jo Berry remembers and reflects on the Brighton bombing which killed her father, Sir Anthony Berry thirty years ago in 1984. She describes her first meeting with one of the bombers, Pat Magee, her growing and unexpected friendship with him and her journey into healing and forgiveness. She elaborates how her understanding of forgiveness has changed and become more nuanced over the years. She also offers reflections on what justice means for her.
\end{abstract}

\section{ANVIL: Tell us a little of your story and how you came to be where you are now?}

Jo: I'll go back to that day when the bomb went off in Brighton and I can't believe it's thirty years ago on October 12 1984. I remember it so well. I woke up to the news that the bomb had gone off at the Grand Hotel and I knew that my dad was staying there with my step mum and I was already someone who was interested in peace and non-violence. I was a meditator, but that didn't really prepare me for the emotional devastation of losing my father in that bomb.

About two days later, I decided to find a way to bring something positive and go on a journey of healing and even understand those who'd killed him, and this was something that was very private - I didn't tell anybody, I just decided that if I could do that then that would make me feel better and would kind of bring meaning to it. And so a journey started and at that time there wasn't anyone I could go to and say 'Look, I want to try and understand what's happened and bring something positive.' You know, there was nobody I could go to... So I felt very much on my own but I trusted and, sure enough, experiences started coming to me and some extraordinary things happened so I began to feel I was progressing. But it was only when we had the peace process that I could start making big steps, and that was back in '99. I did go to Belfast in ' 85 and ' 86 although it was a really difficult time to be there and I did meet some amazing people who shared their stories with me and gave me a sense of what it was like to live there, especially in the West Belfast which was one of the areas in which the IRA came out of.

\section{A: So when you said you started to go on a journey of healing, what did you mean by that?} Jo: I saw that I had an emotional wound and I had a choice, whether to stay hurt, blame someone and be a victim, or I could go on this journey which would heal and transform my wound and if I could turn it around - and I remember thinking that - then that would sort of make sense of it. You know, it wasn't very 'thought out', this was all very new to me - and I was 27 - and I didn't really have any preparation for the emotional depth of what I had been feeling, so it was all very new. And now, there are people who have done this work and I could have gone to them, but at that time there was no one that I knew of. So, yes, I was 
trusting that somehow life would bring the experiences I would need in order to learn. And masses of things happened to me, and took me forward, but it was only in ' 99 that things really, really changed and two things happened. One was that I finally got invited to the first support group for people who had been affected by violence from Northern Ireland who lived in England. Living in England was also quite hard because we were all so spread out. I had never met anyone else apart from my immediate family who had been affected.

\section{A: Who established the support group?}

Jo: was Glencree Reconciliation Centre and , Ian Wight was running it at that time with Colin Parry who had lost his son in the Warrington bomb had got together and there was quite a lot of funds at that time for this kind of work. They created a programme called LIVE Let's involve the Victims and invited people, and paid for all transport costs and everything. That was my first weekend would have been at the beginning of 2000 and was the first time that I ever had any support. It was a long time to wait...

\section{A: It was sixteen years later?}

Jo: Yes, it was a long time to wait...

And now, there is all sorts happen when terrible atrocities happen, but not back in ' 84 . No one ever suggested I would need any help.

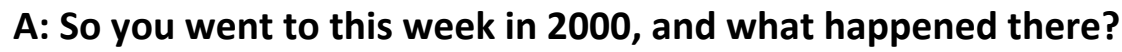

Jo: Well I began to do a lot of releasing of emotions and I found through this process of sharing stories that I was moving fast. And I met other people who felt the same way, people who had been affected by state violence, or loyalist violence or IRA violence. But it didn't matter - we were together sharing stories, and once the formal sessions were over during the day, we would be up all night talking. It was a very important time, and during that year I started to hear about Patrick McGee. He was released in June' 99 and that was part of the Good Friday Peace Agreement. And I had been told that we would all be prepared for that moment, that we would know, but actually...

So, I remember turning on the TV and there was Patrick McGee coming out of prison and that was quite a big shock.

\section{A: When was that?}

Jo: It was June '99 - going back again - but during the year 2000 I heard about him. It's a small world in Northern Ireland and I had always said, literally since '86 - publicly - that I would like to meet him. And so I kept on saying that and people said they would help organise it, and nothing happened. Nothing happened until November 2000 when I got a phone call from my friend in Dublin who said she had arranged for Patrick to be in her house that evening. So could I be there - 7pm - and I was going to go to Dublin anyway that day to go back to Glencree. And I remember I was just so shocked that finally after all these years it 
could happen, and just thinking 'No, no, no, not today - it's not the right day!' But I did say yes, and so off I went to Dublin to meet him.

And then I remember sitting in my friend's kitchen completely sort of shocked really, about what was going to happen and really wondering if it was the best thing to do, but I was going for it anyway. And then he walked in. And that first meeting was three hours long which wasn't at all what I had expected.

As soon as he arrived, he was very polite, quietly spoken and kind of, yes, just very attentive to me and seemed very interested in what l'd been through and was also there to politically sort of justify what he... Well, he wasn't so much as speaking as ' $l$ ', he was speaking in terms of ' $w e^{\prime}$ - of the IRA - and he was no longer a member of the IRA...

\section{A: How did it make you feel - his speaking in terms of the IRA?}

Jo: Well, I was quite familiar, because I had met other men who had been in the IRA which had actually been very useful. I was quite familiar with the justification, the rhetoric, the reasons... I listened and remembered thinking 'I probably won't come back for a second visit', but I am getting a lot out of the first one, because I can see he is someone who is a deep thinker and someone who has really thought about it as opposed to just simply 'following'. He was being sensitive to me, so I was getting what I wanted out of it. All I really wanted was a face behind the enemy, behind the label, behind the word 'terrorist' which is such a scary label. I wanted to meet a human being and I was having that experience. And he was giving me what I needed, but I was thinking this would be a one-off meeting, that I wasn't coming back for a second visit, because he is justifying killing my father and obviously for me, my father, being killed in that way, has affected my life. So, I was quite clear about that - that I wouldn't go back for a second visit.

\section{A: He was justifying the murder?}

Jo: Yes, politically. Politically, he was justifying it. And he was there, I suppose, to show that they had thought it through and they weren't just 'evil bastards' or whatever they had been called by the press.

So, just when I was thinking that, there was this moment when he stopped talking, and he looked at me and said 'I don't know any more what to say, I don't know who I am. I want to hear your anger and your pain and what can I do to help you. And that was when he took off the 'political hat' and opened up, and was very much more about his personal response. The conversation was completely different after that. And what had just been about my need had become about his need as well, as he began to recognise that he was guilty of demonising the other and he lost some of his humanity through choosing this violence. He became aware that he had some healing to do. He had felt that I was the one who had the need and he was just there to help, but it completely changed. 
A: So you think that, for him, it only changed in that encounter with you, at that moment? Jo: Yes, he said he was 'disarmed' by the fact that I gave him empathy, and that if I had gone there arguing, and gone there arguing that 'I am right, and you are wrong,' then he could have stayed in this political position.

\section{A: So that was quite disconcerting for him, perhaps?}

Jo: Yes, he wasn't expecting that...

\section{A: So you really met on common ground as two human beings who were really suffering?} Jo: Yes, Yes!

\section{A: Were you expecting that?}

Jo: No. No, I mean, it was far more than I had bargained for at the time. and thinking 'Oh my God, I think I am just going to run away from this - it is just too much.' And then another part of me thinking that, actually, this is just what I need - this is fantastic, another journey. And I remember on the ferry thinking that I had been working towards meeting this goal that is, meeting the man who had killed my father - and that I didn't have anything beyond that. That was it! And I was almost thinking 'Oh!' I look back and it seems rather funny'What is it that I am going to do after this meeting, I have got to think of something else!' But, of course, as soon as I was with him and this happened, then another journey started and one which was really challenging for us both, I think.

\section{A: So what does it mean to call Pat a friend?}

Jo: It took me a long, long time before I called him my friend. It was only when I decided that I could call him my friend because I care about him. And I am extremely grateful for his engagement with me and his involvement and his trusting me. And he does trust me and I trust him and we have done some most extraordinary things together in a way I wouldn't have done that unless there was that caring and their friendship.

Last year we were in Palestine and Israel together for eight days. I had organised the whole trip and found the funding. And at the end of these really long days of travelling and meeting people which was so intense, there was only he and I, you know, giving each other support, and in the morning at breakfast. And that is a friendship because we are relying on each other - I was talking things through with him and he was relying on me, and having spent all that time together, I still, at the end of the time, was enjoying being with him, even though sometimes it can be challenging and I can get frustrated. But there is that sense of trust, and what we have experienced together after all these years, is just so much.

\section{A: Can you tell me a little bit about that journey, how you came to call him a friend? Jo: Well I was always wanting to make a difference between him and what he did, if that makes sense. I never wanted to blame him. And the more I got to know him, the more I understood why he did what he did. And I have been able to separate what I've been}


through and him. So I haven't been making him responsible for my pain and that, I suppose, has been the way right from the beginning. I thought if I made him responsible for my pain then that would link him with me in an unhealthy negative way for ever. You know, he would be in my head as the perpetrator and I didn't want that. So, right at the beginning in ' 84, I decided I wasn't going to do that, I would take responsibility. I don't feel responsible for what happened, I wasn't in control that day of the bomb going off, but I have complete control of how I respond. And that has kind of helped me to see him as someone who - what he did, is different from who he is. And that has really, really helped. I suppose the friendship has come because of the work that we have been doing together, and the amount of times we have spoken without a clue of what we are going to say - we never prepare it.

\section{A: What is the work that you do together?}

Jo: Well we have spoken together over 120 times and also facilitated workshops. And what we do when we speak is that we - and we're talking about speaking in schools, universities, cross-community groups in Northern Ireland, prisons - different parts of the world Rwanda, Spain, Palestine. He couldn't come to America with me but did a satellite link there - all over England... There are so many times, and each time is different because we speak from where we are that day. I never know what he's going to say, and he never knows what I am going to say. And then, we usually respond to what each other has said, so that it is always alive and real, and then we open it up for questions and then that for me becomes a really interesting part because new conversations can then start. This is because we're almost breaking a taboo as we're saying that we're not enemies and we see each other's humanities and we listen with respect and give each other dignity and then that fosters a new conversation. In Palestine and Israel, it was seeing their own conflict mirrored back in a different way, or in Northern Ireland it invites people sharing their stories or talking about some of the difficult issues. If I am in schools, then they can be talking about the death penalty. You know, whatever, it's always different. It's never that same - never, ever the same. And it always creates this connection with people in the audience, even if people are challenged, there is still like a connection there.

And with the workshop, I am trained as a facilitator and I can teach skills or create a safe place for stories or whatever is necessary and I want to be doing more of that. We have done some of that. In workshops we take these ideas and give people small groups to look at conflict in their lives or how they can bring empathy to someone, or that kind of thing, to go sort of deeper into it.

\section{A: I guess that's very challenging and very helpful for people}

Jo: Yes, I think it is because we're not there as academics or experts, but as people who have been through it. It gives them something different. 


\section{A: It is now thirty years since the bomb exploded killing your father. Do you think you remember this event differently as the years have progressed?}

Jo: I've definitely felt differently - the pain has changed. Yes... and that's because of the fantastic support I've had and that's because of the work that I've been doing to transform those feelings. So the pain is different. And yet, I still have some of that pain. It's sort of odd, really. There's still a wound there and maybe that's never going to go away and maybe that's fine. I've certainly lived with it and integrated it and am grateful for what's unfolded since then, but that doesn't mean I wanted it to happen though. The story's changed because it's not just the wound, there's all the other bits afterwards and there is so much that has happened. Just the people in my life whom I would never have met and the opportunities to make a difference which are incredible. The doors that have opened and that has all added to the story and looking at my friendship with Pat which I never, ever would have dreamt was possible back in '84.

\section{A: What does it mean for justice to be done. Could we say justice was done because he was convicted and he served his sentenced?}

Jo: That's not justice for me.

\section{A: So what is justice for you?}

Jo: I've been thinking about it the other day, that what means most to me is that he now sees my dad as a human being and knows he could have sat down and had a cup of tea with him, and when he planted that bomb he wasn't seeing human beings. So it's a bit like the restorative justice process. And that is what I feel is the most important thing, because he now, I suppose, takes full responsibility for what he did. He can't just see it as a political device. He still does in one part of him, but one part of him knows that he killed human beings. I think that actually re-humanised him and it means so much to me. I don' know whether that's justice - or what that is - but that seems to me to be the most important thing. It's brought my dad back in a different way. So between us he knows - and he often says it when we speak - that he killed a wonderful human being and he knows that because of knowing me really well and some of my qualities would have come from him, so he's sort of worked that out. Of course the reality is, you know, that the British Government were never going to sit down with the IRA at that time. But that's not the point. The point is that now he sees him as a human being and, as we know, most people when they are using violence in wars, whether they are trained soldiers or whether they are terrorists or combatants, they take away the human element, else they wouldn't be able to do it. Perhaps Pat wouldn't have been able to plant that bomb if he had known my dad.

\section{A: In some ways, that's a deep and terrible kind of justice, isn't it - knowing you have actually killed another human being... yeah! ...to own up to that...}

Jo: Yeah, I think that's very brave, and that means more to me than prison. But if he hadn't have been to prison, I wouldn't have known who he was, so I couldn't have started the relationship. So I am grateful to prison for that. I know other people who would quite like to 
meet the persons who killed their loved ones, but they don't know who they are, because they have never been caught. So, I do feel lucky that, in a way, he did go to prison.

\section{A: And what about forgiveness - what does forgiveness mean to you, or how do you understand forgiveness?}

Jo: That's changed over the years. It has completely changed. Well, when I was 28,29 , I was kind of using that all the time - 'Yes, you're forgiven' and it was a kind of easy thing to say, that is was an idea I had and that was that. But I hadn't, at that time, felt the rage, the rage came later. It did seem quite simple. And now, the more I am on this journey, the more complex forgiveness is, and it can seem to be sort of a righteousness thing - you know, I am going to forgive you all these terrible things, and aren't I a good person to do it. So it keeps you as someone who has done no wrong and I just don't feel happy about. What makes sense to me is to see it as this: knowing that if I'd lived his life, I might have made the same choices, and that's about deep empathy. And, you know, I don't know how I would have behaved. I mean, I may not have. There's always going to be a question mark. And that isn't even about forgiveness at that point. It's just about the understanding. That liberates me. I can experience from people from all sides and that helps me to see that actually, there is a sort of paradigm where there are no sides and there is no enemy and that there is just of us struggling to do our best. And when we hear each other's story, then there is just this sense of, like, 'Gosh I don't know how I would have been in those circumstances' and I can apply that. When I was in Rwanda I was applying that there and when I was in Bosnia that's sort of how I like to see people. And it wouldn't have occurred to me if I hadn't been having this dialogue with Pat, and I am very grateful for that insight. There is a place where it is just about all of us struggling to do our best with huge limitations, and it's so easy to divide the world into us and them and right and wrong. And I think that that's part of the problem of everything. If the IRA had been really held and listened to, then you know... these weren't people who, at the age of three, decided that they wanted to be violent. You know, I have met enough men in the IRA to know that they are just normal people. It's a lot easier to put people out there and go 'there're beyond the pale. You know it kind of makes us feel better, but I am more interested in actually dealing with the fact that there really is no other. Of course their behaviour has got to be challenged and there are... but that's a whole other subject.

\section{A: So are you saying that, in a way, forgiveness puts you in a position, or in an unhealthy position of power over...}

Jo: It can do, I've seen it - can do...

\section{A: Is there such a thing as 'healing of memories?' \\ Jo: Do you know the work of Michael Lapsley?}




\section{A: I do, because he's a New Zealander!. Perhaps you could explain who Michael Lapsley is and what he does.}

Jo: Okay. He has the Healing Memories Institute in South Africa and he himself was a victim of a letter bomb and he doesn't know who sent it, but he was working with ANC and against apartheid, so it was probably the government at the time. He lost one eye and his arms, and he had devised this healing of memories which is a safe way for stories to be heard and for people of different backgrounds and communities and former enemies can come together and share their stories. And I have seen this process many times and it's incredible.

\section{A: He's still doing it, is he?}

Jo: Oh yes in Capetown. Yes, he's written a book. And he's got an interesting view on forgiveness because he calls it 'bicycle forgiveness' Have you heard of his 'bicycle forgiveness?'

\section{A: No, what does that mean?}

Jo: Okay, well, he doesn't know who caused his injuries- well, he has an idea, but he hasn't got a name - and until he knows, he doesn't really think he can forgive, because for him it is connected to the past, for which some people's forgiveness is definitely connected to having a name and a person who takes some accountability and responsibility. He has to now have a permanent carer with him, because he can't look after himself. So, he said if he forgives this guy, then it's like someone steals your bicycle - they've got your bicycle - you say you forgive them, but they've still got the bicycle. There's got to be something back... So, for him, I think if he ever did find anyone, he would like them to pay for his carer. That would mean something.

\section{A: So, maybe that's justice.}

Jo: Yes, exactly. Maybe that's justice... That is like a restorative justice, isn't it?

\section{A: That's quite a good metaphor, bicycle forgiveness.}

Jo: I'm [also] thinking of Colan Parry who lost his son in the Warrington bombing and he says he doesn't have a name for the person who planted this bomb and he hasn't forgiven them. And he has met - well, Martin McGuiness came to Warrington and gave a talk recently, and I think he has met Gerry Adams.. He does incredible work bringing together people from different parts of the community in Northern Ireland. And his peace work - and he says he doesn't forgive, and he's really compassionate.

\section{A: So it's obviously a lot more complex. Sometimes we are a little trite about it, aren't we?} Jo: And also, I met a lovely, amazing woman. I was in Leeds working with a group of asylum seekers and she had escaped from Kenya, and she said to me in a very personal one to one that she goes to church every Sunday - very religious, very Christian - and that she feels she is a very bad Christian because she has still got feelings of anger towards these people who totally abused her, and she thought she shouldn't have them, and therefore she feels like 
she is a really bad person. And when I said to her, 'I think you're amazing', because I could see she was an amazing person - so brave - and actually it's a journey and anger has got a part to play on this journey. Yes, the relief just came to her and she felt that she could go back to her religion - follow her religion. And that's another reason why I worry about it. It puts pressure on people. You know, are you allowed to have anger if you have forgiven?! There are some people who have these experiences of forgiveness and then that's it, they have got inner peace and they are completely at one. I have met people like that. Other people really struggle. And I think we have to have a way for that struggle to be absolutely fine, and honour it, honour the struggle.

A: Yes, thank you. Just carrying on thinking about memories and remembering. There's a Croatian theologian called Miroslav Volf who has written a book entitled 'The end of memory: remembering rightly in a violent world.' What does remembering rightly mean for you?

Jo: Well, I suppose the work 'rightly' does sound a bit like it's going to be the same for everyone, and I would feel that - I haven't read the book and don't know what he means by it... I hope he would mean that everybody has got their own way of... remembering rightly... I would see the word 'transformation' in there.

\section{A: So that your memories are transformed to help you go forward...}

Jo: Yes... But they are still there. I don't actually want to forget what happened that day, so I don't want my memory to end. What I want is to live in a world where all our truths are honoured and so, in that truth, there's the truth of the people who were in the hotel, there's the truth of the people who planted the bomb, there's the truth of what is going on in Belfast. So we are able to see the whole picture...

\section{A: So, yes, that's an important point, isn't it?}

Jo: Yes. So I'm not the only one who's got an experience, that's got a truth, that's got a memory of it, and the pain of the person from the other side is my pain. And the question when we honour all the truth is how we can work together to change this and make sure that the pain of the past isn't going to create more pain in the future. Can we learn from it?

\section{A: And not cripple us in the present...}

Jo: Yes, exactly. And not cripple us in the present. Exactly. I really do believe we can change the person and it is about recognising that there are many, many narratives and each one is valid. Each person has their story, and each person needs to be heard and witnessed, and needs the support. 
A: Finally, thank you so much for your insights. And the last question is - just briefly, is there anything you would like to say to those who have tragic or agonising memories that you haven't said so far?

Jo: I just wish everyone had the opportunity to have their story heard and the support that they need, and that whatever anyone is feeling at any one time is understandable. I think that is what I would have liked someone to have said to me back in the early days.

Let's say I am listening to someone. I am not thinking of solutions or answers, I am not thinking of what they need, I'm not thinking 'Gosh, they should have let go by now... I am taking away that part of me that would analyse it, or judge it, or therapise it. Just witnessing. Witnessing is that 'just being there' for that person. And any question that I might ask might be only to help them to feel safer to go deeper into their story or to feel held.

\section{A: So is it reliving it with them?}

Jo: Yes. Yes. I'm creating a safe place for them to go into it. They would be held while they go into it, and I think that is one of the best ways to be able to move on.

\section{A: You know, any human being can offer that to another human being...}

Jo: You can, but you've got to be not scared of pain. You've got to really know yourself if you're the listener.

\section{A: But you don't have to be a trained psychiatrist or whatever...}

Jo: You don't have to be a psychiatrist, because I can do it, and I'm not trained. I am trained in other ways though - yes.

\section{A: But it's something we could offer to one another...}

Jo: Exactly. Yes.

\section{A: Jo, thank you so much for your time and insights.}

Jo Berry has founded a charity 'Building Bridges for Peace' and has worked for over 14 years to resolve conflict around the world. In 2000, sixteen years after her father was killed by an IRA bomb, Jo first met with the man responsible, Pat Magee. They have now spoken together over 150 times around the world. Their story can be seen in the documentary Beyond Right and Wrong. 